Jurnal Tarbawi| Volume 2|No 1| ISSN 2527-4082| 24

\title{
KINERJA DOSEN PENDIDIKAN AGAMA ISLAM DALAM MENINGKATKAN EFEKTIFITAS PEMBELAJARAN
}

\author{
Sandi Pratama ${ }^{1}$, Amirah Mawardi ${ }^{2}$ \\ ${ }^{* 1}$ Pendidikan Agama Islam Fakultas Agama Islam| Unismuh Makassar \\ ${ }^{* 2}$ Pendidikan Agama Islam Fakultas Agama Islam| Unismuh Makassar
}

\begin{abstract}
ABSTRAK
Penelitian yang digunakan adalah Penelitian lapangan (field research), adapun lokasi penelitian bertempat di Fakultas Agama Islam Universitas Muhammadiyah Makassar. Jumlah Populasi dalam penelitian ini 860 Orang sedangkan Sampelnya 51 Orang. Data primer yang diperlukan dalam penelitian ini diperoleh melalui instrument pokok berupa kuesioner atau angket. Sedangkan observasi, wawancara dan dokumentasi digunakan untuk melengkapi data yang diperoleh. Seluruh data yang terkumpul selanjutnya diolah dan dianalisis dengan menggunakan analisis deskriptif kualitatif kedalam bentuk yang sesuai. Hasil Penelitian yang dilakukan, secara detail dari 48 jumlah angket yang disebar secara signifikan membuktikan bahwa Kinerja dosen Pendidikan Agama Islam sangat mempengarui efektifitas pembelajaran di Fakultas Agama Islam, Hal ini dapat dilihat dalam proses belajar mengajar, menjadi teladan dan metode-metode mengajar lainya. Dapat dilihat dari hasil tabulasi data yaitu dosen yang mengajar sesuai kurikulum 75\%, Menjadi teladan 93.75\%, memberikan sapaan $60.5 \%$, penguasaan materi $81.25 \%$, metode yang baik $72.92 \%$, pemberian motivasi $75 \%$, penjelasan yang baik $60.5 \%$, penggunaan media $31.25 \%$, pemberian jawaban $75 \%$ dan melakukan teguran $43.75 \%$.
\end{abstract}

Kata Kunci: Kinerja Dosen, Efektifitas Pembelajaran

\begin{abstract}
The research used is field research (field research), while the location of research located at the Faculty of Islamic Studies Muhammadiyah University of Makassar. The population in this study 860 people whiles the sample 51 people. Primary data needed in this research is obtained through principal instrument in the form of questionnaire or questionnaire. While observation, interview and documentation is used to complete the data obtained. All the data collected then processed and analyzed by using qualitative descriptive analysis into the appropriate form. The results of the research, in detail from 48 the number of questionnaires spread significantly proved that the performance of Islamic Religious lecturers strongly affects the effectiveness of learning in the Faculty of Islam, This can be seen in the process of teaching and learning, be an example and other teaching methods. Can be seen from the data tabulation of lecturers who teach according to the curriculum $75 \%$, Being an example of $93.75 \%$, giving $60.5 \%$ greeting, mastery of material $81.25 \%$, good method $72.92 \%, 75 \%$ motivation, good explanation $60.5 \%$, media usage $31.25 \%$, Giving $75 \%$ answer and $43.75 \%$ strike.
\end{abstract}

Keywords: Lecturer Performance, Effectiveness of Learning 


\section{PENDAHULUAN}

Pendidikan

\section{kebutuhan}

manusia

mempersiapkan

generasi

untuk

berkualitas karena pendidikan dapat dijadikan bekal untuk menghadapi berbagai masalah yang muncul di masyarakat. Pendidikan memuat pengetahuan, sikap, dan keterampilan yang diperlukan manusia. Ketiga aspek tersebut dapat diperoleh melalui pendidikan formal maupun nonformal. Selain itu, pendidikan juga merupakan sarana penunjang kemajuan manusia yang berwawasan ke masa depan.

Perguruan tinggi memiliki visi, misi, dan tujuan yang pencapaiannya dilakukan melalui Tri Dharma Perguruan Tinggi, yaitu kegiaan pendidikan dan pengajaran, penelitian, dan pengabdian masyarakat. Dalam hal ini dosen merupakan unsur utama dalam kegiatan Tri Dharma Perguruan Tinggi karena dosen turut berperan dalam meningkatkan kualitas pendidikan. Sejalan dengan perkembangan ilmu pengetahuan dan teknologi, bahwa untuk meningkatkan kualitas perguruan tinggi dilakukan peningkatan manajemen perguruan tinggi yang berlangsung secara berkesinambungan.

Kenyataan di lapangan, masih banyak masalah yang ditemukan di perguruan tinggi. Hasil penelitian Ilyassin menemukan permasalahan bahwa kemampuan mahasiswa dalam memecahkan masalah masih rendah, kurang terjalinnya komunikasi antar unsur pimpinan, belum terdapat kesamaan visi dalam mengembangkan lembaga, dosen masih menggunakan pola-pola pembelajaran konvensional, masih terdapat kesenjangan komunikasi antara pimpinan, dosen dan pegawai, dan dalam mengerjakan tugas dosen masih menunggu perintah daripada berinisiatif. Permasalahan kinerja dosen terdapat juga di Universitas Muhammadiyah Makassar yang merupakan sebuah perguruan tinggi swasta yang dibawah naungan persyerikatan muhammadiyah, Universitas Muhammadiyah Makassar mempunyai jumlah mahasiswa yang sangat banyak dibandingkan perguruan tinggi lainnya yang ada di Sulawesi selatan, tercatat pada tahun 2013 jumlah mahasiswa Universitas Muhammadiyah Makassar mencapai 36 ribu jiwa dari 7 fakultas dan 24 program study. Fakultas Agama Islam merupakan sebuah Fakultas tertua yang ada di Universitas Muhammadiyah Makassar, Fakultas pertama ialah Fakultas Agama Islam. System pembelajaran di Fakultas ini lebih menekankan pada aspek penguatan spiritual tanpa melupakan aspek yang lainnya. Pencapaian proses belajar mengajar di Fakultas Agama Islam dalam mencapai tujuan dari fakultas ini ditentukan oleh pola pengajaran dan pembinaan yang efektif. Allah SWT berfirman dalam Surah Al-Baqarah ayat 124, yaitu: 


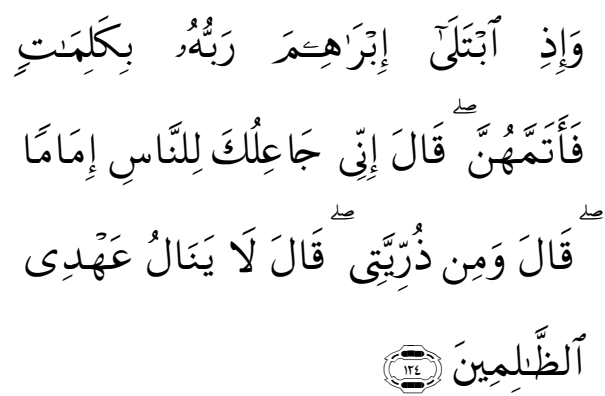

Terjemahan: "Dan (ingatlah), ketika Ibrahim diuji Tuhannya dengan beberapa kalimat (perintah dan larangan), lalu Ibrahim menunaikannya. Allah berfirman: "Sesungguhnya aku akan menjadikanmu imam bagi seluruh manusia". Ibrahim berkata: "(Dan saya mohon juga) dari keturunanku", Allah berfirman: "Janji-Ku (ini) tidak mengenai orang yang zalim" (Kementrian Agama:2009:15).

Proses belajar mengajar merupakan serangkaian aktivitas yang terdiri dari persiapan, pelaksanaan, dan evaluasi pembelajaran. Ketiga hal tersebut merupakan rangkaian utuh yang tidak dapat dipisah pisahkan. Persiapan belajar mengajar merupakan penyiapan satuan acara pelajaran (SAP) yang meliputi antara lain standar kompetensi dan kompetensi dasar, alat evaluasi, bahan ajar, metode pembelajaran, media/alat peraga pendidikan, fasilitas, waktu, tempat, dana, harapan-harapan, dan perangkat informasi yang diperlukan untuk mendukung pelaksanaan proses belajar mengajar. Kesiapan siswa, baik fisik maupun mental, juga merupakan hal penting.
Berdasarkan pada latar belakang masalah yang dikemukakan di atas, maka dikemukakan beberapa rumusan masalah sebagai berikut :

1. Bagaimana kinerja dosen Pendidikan Agama Islam di Fakultas Agama Islam Universitas Muhammadiyah Makassar?

2. Bagaimana efektifitas pembelajaran di Fakultas Agama Islam Universitas Muhammadiyah Makassar?

3. Bagaimana kinerja dosen Pendidikan Agama Islam dalam Meningkatkan Efektifitas Pembelajaran di Fakultas Agama Islam Universitas Muhammadiyah Makassar?

\section{METODE PENELITIAN}

Jenis penelitian ini adalah penelitian deskriptif Kualitatif, dengan pendekatan korelasional yang bertujuan untuk menyajikan data kedalam bentuk kata yang sesuai. Lokasi penelitian ini bertempat di Fakultas Agama Islam Universitas Muhammadiyah Makassar dengan pertimbangan bahwa di Fakultas ini ada beberapa masalah yang menarik untuk diamati dan diteliti terkait efektifitas pembelajaran sedangkan objek penelitian ini adalah dosen dan sebahagian Mahasiswa di Fakultas Agama Islam Universitas Muhammadiyah Makassar. 
Keadaan Populasi

\begin{tabular}{|l|l|c|c|}
\hline No. & $\begin{array}{c}\text { Nama } \\
\text { Sampel }\end{array}$ & $\begin{array}{c}\text { Total } \\
\text { Sampel }\end{array}$ & Jumlah \\
\hline 1. & Dosen & 3 & 3 \\
\hline 2. & Mahasiswa & & \\
& Semester VI & 8 & \\
& Kelas A & 8 & \\
& Kelas B & 8 & 48 \\
& Kelas C & 8 & \\
& Kelas D & 8 & \\
& Kelas E & 8 & \\
Kelas F & & \\
\multicolumn{2}{|l}{} \\
\hline
\end{tabular}

Keadaan Sampel

\begin{tabular}{|c|c|c|c|c|}
\hline \multirow[t]{2}{*}{ No } & \multirow[t]{2}{*}{ Populasi } & \multicolumn{2}{|c|}{$\begin{array}{c}\text { Jenis } \\
\text { Kelamin }\end{array}$} & \multirow[t]{2}{*}{ Jumlah } \\
\hline & & LK & PR & \\
\hline 1. & Dosen & 15 & 18 & 33 \\
\hline 2 & $\begin{array}{l}\text { Mahasiswa } \\
\text { Semester II }\end{array}$ & 83 & 200 & 283 \\
\hline 3. & $\begin{array}{l}\text { Mahasiswa } \\
\text { Semester IV }\end{array}$ & 59 & 195 & 254 \\
\hline 4. & $\begin{array}{l}\text { Mahasiswa } \\
\text { Semester VI }\end{array}$ & 69 & 254 & 323 \\
\hline & Total & 211 & 649 & 860 \\
\hline
\end{tabular}

HASIL PENELITIAN DAN PEMBAHASAN

A. Kinerja Dosen Pendidikan Agama Islam di Fakultas Agama Islam Universitas Muhammadiyah
Jurusan Pendidikan Agama Islam merupakan sebuah jurusan yang menjadi patron untuk jurusan lain yang ada diuniversitas Muhammadiyah Makassar, selain tergolong jurusan ini merupakan sebuah jurusan pertama yang mengawali kiprah dari universitas muhammadiyah Makassar, jurusan inipun mempunyai tanggung jawab besar karena mengenakkan identitas islam didalamnya sehingga orang-orang yang bergelut didalamnya baik itu dosen maupun mahasiswa mempunya beban moril didalamnya.

Terlebih lagi dosen yang mempunyai peran sentral dalam pengembangan mahasiswa, mempunyai tanggung jawab lebih selain mampu melakukan transformasi ilmu, dosen juga diharuskan menjadi contoh untuk mahasiswa. Dosen Pendidikan agama islam lebih besar lagi tanggung jawabnya, selain menjadi patron untuk mahasiswa dosen pendidikan agama islam juga menjadi patron untuk dosendosen lain yang ada di universitas muhammadiyah Makassar.

Untuk mengukur kinerja dosen pendidikan agama islam dapat dibuktikan dengan adanya respon positif dari mahasiswa terhadap kuisioner (angket) yang dibagikan pada siswa diakhir penelitian, yang dapat dilihat melalui tabulasi-tabulasi angket berikut ini. 
Materi Kuliah Yang Diajarkan Oleh Dosen Yang Sesuai Kurikulum

\begin{tabular}{|c|c|c|c|}
\hline No. & $\begin{array}{c}\text { Alternatif } \\
\text { Jawaban }\end{array}$ & Frekuensi & $\begin{array}{c}\text { Persen } \\
\text { tase }\end{array}$ \\
\hline 1. & Ya & 36 & $75 \%$ \\
\hline 2. & Kurang & 9 & $\begin{array}{c}18.75 \\
\%\end{array}$ \\
\hline 3. & Tidak & 3 & $6.25 \%$ \\
\hline \multicolumn{2}{|c|}{ Jumlah } & 48 & $100 \%$ \\
\hline
\end{tabular}

Dari tabulasi angket dapat diketahui bahwa Dosen yang mengajarkan mata kuliah yang mengikuti kurikulum yang ada, ada 36 Mahasiswa yang mengatakan "Ya" (75\%), dan yang menyatakan "Kurang" sebanyak 9 Mahasiswa (18.75\%), dan yang menyatakan "Tidak" sebanyak 3 Mahasiswa (6.25\%). Sehingga peneliti mengambil kesimpulan bahwa Dosen di Jurusan Pendidikan Agama Islam Mengikuti Kurikulum pada saat proses belajar mengajar.

\section{Dosen Menjadi Teladan Dalam Berpakaian Buat Mahasiswa}

\begin{tabular}{|c|c|c|c|}
\hline No. & $\begin{array}{c}\text { Alternatif } \\
\text { Jawaban }\end{array}$ & Frekuensi & $\begin{array}{c}\text { Persen } \\
\text { tase }\end{array}$ \\
\hline 1. & Ya & 45 & $\begin{array}{c}93.75 \\
\%\end{array}$ \\
\hline 2. & Kurang & 2 & $4.17 \%$ \\
\hline 3. & Tidak & 1 & $2.08 \%$ \\
\hline & Jumlah & 48 & $100 \%$ \\
\hline
\end{tabular}

Dari Tabel diatas dapat diketahui bahwa respon menjawab "Ya" sebanyak 45 Mahasiswa (93.75\%), “Kurang” sebanyak 2 Mahasiswa (4.17\%), dan yang menjawab "Kurang" sebanyak 1 Mahasiswa (2.08\%). Peneliti dapat mengambil kesimpulan bahwa Dosen Jurusan Pendidikan Agama Islam menjadi Teladan buat para mahasiswa khususnya dalam berpakaian.

Dalam mewujudkan kinerja dosen yang baik, semua pihak perlu terlibat terutama pihak pimpinan fakultas yang menjadi elemen penting dalam mengukur kinerja dosen di jurusan pendidikan agama islam. Pimpinan fakultas harus bersikap tegas kepada dosen yang senantiasa melenceng dari aturan pimpinan fakultas seperti dosen yang tidak mengikuti kurikulum dalam mengajar atau melanggar aturan-aturan lainnya. Pimpinan harus senangtiasa melakukan evaluasi sebagai upaya memantau kinerja-kinerja dosen pendidikan agama islam.

\section{B. Efektifitas \\ Pembelajaran \\ Mahasiswa di Fakultas Agama Islam Universitas Muhammadiyah Makassar}

Efektifitas pembelajaran diukur dari kualitas dosen yang memberikan sebuah pembelajaran, ketika dosen melakukan kerja-kerja efektif dalam memberikan mata kuliah maka hasilnya pun kepada mahasiswa akan efektif. Untuk mewujudkan pembelajaran yang efektif dosen memerlukan metode yang membuat mahasiswa betah dalam menerima sebuah pembelajaran. Untuk 
Mengukur efektifitas pembelajaran yang dilakukan oleh Dosen Pendidikan Agama Islam dapat melihat Tabulasi berikut ini:

Mahasiswa Menyukai Metode Dosen dalam Mengajar

\begin{tabular}{|c|c|c|c|}
\hline No. & $\begin{array}{c}\text { Alternatif } \\
\text { Jawaban }\end{array}$ & Frekuensi & $\begin{array}{c}\text { Persen } \\
\text { tase }\end{array}$ \\
\hline 1. & Ya & 35 & $\begin{array}{c}72.92 \\
\%\end{array}$ \\
\hline 2. & Kurang & 9 & $\begin{array}{c}18.75 \\
\%\end{array}$ \\
\hline 3. & Tidak & 4 & $8.33 \%$ \\
\hline \multicolumn{2}{|c|}{ Jumlah } & 48 & $100 \%$ \\
\hline
\end{tabular}

Dari tabulasi angket dapat diketahui bahwa Mahasiswa yang menyukai Metode dosen dalam mengajar, mengatakan "Ya" 35 Mahasiswa (72.92\%), dan yang menyatakan "Kurang" sebanyak 9 Mahasiswa (18.75\%), dan yang menyatakan "Tidak" sebanyak 4 Mahasiswa (8.33\%). Sehingga peneliti mengambil kesimpulan bahwa Mahasiswa menyukai metode yang diajarkan oleh dosen didalam proses belajar mengajar.

Dosen memberikan Motivasi didalam Proses Belajar Mengajar

\begin{tabular}{|c|c|c|c|}
\hline No. & $\begin{array}{c}\text { Alternatif } \\
\text { Jawaban }\end{array}$ & Frekuensi & $\begin{array}{c}\text { Persen } \\
\text { tase }\end{array}$ \\
\hline 1. & Ya & 36 & $75 \%$ \\
\hline 2. & Kurang & 11 & 22.92 \\
\hline
\end{tabular}

\begin{tabular}{|c|c|c|c|}
\hline & & & $\%$ \\
\hline 3. & Tidak & 1 & $2.08 \%$ \\
\hline & Jumlah & 48 & $100 \%$ \\
\hline
\end{tabular}

Dari Tabel diatas dapat diketahui bahwa respon menjawab "Ya" sebanyak 36 Mahasiswa (75\%), "Kurang” sebanyak 11 Mahasiswa (22.92\%), dan yang menjawab "Kurang" sebanyak 1 siswa (2.08\%). Peneliti dapat mengambil kesimpulan bahwa Dosen pendidikan agama islam memberikan motivasi didalam proses belajar mengajar sebagai tujuan membangkitkan semangat mahasiswa dalam belajar.

Penjelasan Dosen Dapat Dipahami Dengan Baik

\begin{tabular}{|c|c|c|c|}
\hline No. & $\begin{array}{c}\text { Alternatif } \\
\text { Jawaban }\end{array}$ & Frekuensi & $\begin{array}{c}\text { Perse } \\
\text { ntase }\end{array}$ \\
\hline 1. & Ya & 30 & $60.5 \%$ \\
\hline 2. & Kurang & 16 & $33.33 \%$ \\
\hline 3. & Tidak & 2 & $4.17 \%$ \\
\hline \multicolumn{2}{|c|}{ Jumlah } & 48 & $100 \%$ \\
\hline
\end{tabular}

Dari tabulasi angket diatas dapat diketahui bahwa respon yang menyatakan "Ya" sebanyak 30 Mahasiswa (60.5\%), yang mengatakan "Kurang" sebanyak 16 Mahasiswa (33.33\%) dan “Tidak" sebanyak 2 Mahasiswa (4.17\%). Sehingga peneliti berkesimpuan bahwa Penjelasan dosen didalam proses belajar mengajar dapat dipahami dengan baik oleh para mahasiswa. 
C. Kinerja Dosen Pendidikan Agama Islam dalam Meningkatkan Efektifitas Pembelajaran di Fakultas Agama Islam Universitas Muhammadiyah Makassar

Kinerja Dosen Pendidikan Agama Islam di Fakultas Agama Islam sudah cukup baik dalam meningkatkan efektifitas Pembelajaran di Fakultas Agama Islam Universitas Muhammadiyah Makassar hal ini terbukti dengan tabulasi angket yang dibagikan kepada mahasiswa. Dapat dilihat hasil tabulasi penelitian yaitu dosen yang mengajar sesuai kurikulum $75 \%$, Menjadi teladan 93.75\%, memberikan sapaan $60.5 \%$, penguasaan materi $81.25 \%$, metode yang baik $72.92 \%$, pemberian motivasi $75 \%$, penjelasan yang baik $60.5 \%$, penggunaan media $31.25 \%$, pemberian jawaban $75 \%$ dan melakukan teguran 43.75\%. Hal ini tidak terlepas dari peran segala pihak baik Pimpinan Fakultas, Dosen dan Mahasiswa itu sendiri.

Dalam meningkatkan efektifitas pembelajaran di Fakultas Agama Islam ditentukan oleh Kinerja Dosen itu sendiri, semakin baik kualitas dari kinerja dosen maka pembelajaran di fakultas agama islam semakin efektif. Dosen berperang sebagai pemberi (Keteladanan dan ilmu) sedangkan Mahasiswa berperang sebagai penerima sehingga antara dosen dan mahasiswa, antara pemberi dan penerima harus mempunyai sinergitas. Untuk mewujudkan sebuah sinergitas keduaduanya (Dosen dan Mahasiswa) harus berperang aktif seperti Dosen yang menjadi sentral utama dapat menjadi contoh sebelum memberi contoh dan mahasiwa yang diberi contoh dapat melaksanakan contoh itu dengan baik sehingga tujuan didalam proses belajar mengajar dapat terwujud sesuai dengan harapan bersama.

Untuk mewujudkan sebuah efektifitas pembelajaran dalam proses pembelajaran diperlukan sebuah Dosen yang berkualitas tetapi untuk mewujudkan dosen yang berkualitas Pimpinan Fakultas Agama Islam mempunyai peran sentral untuk mewujudkannya. Ketika kinerja dosen pendidikan agama islam baik, sebagai pimpinan di Fakultas Agama Islam harus memberikan sebuah dukungan untuk dosen yang bersangkutan tetapi jika kinerja dosen Pendidikan Agama Islam kurang baik maka sebagai pimpinan harus menindaklanjuti dosen tersebut.

Ketegasan dari pihak pimpinan fakultas untuk menindaklanjuti dosen Pendidikan Agama Islam yang mempunyai kinerja kurang bagus di Fakultas Agama Islam harus efektif jika ingin melahirkan kinerja dosen yang efektif pula. Wawancara yang peneliti lakukan dengan Dekan Fakultas Agama Islam yakni Bapak Drs. H. Mawardi Pewangi, M.Pd.I selaku Dekan Fakultas Agama Islam Universitas 
Muhammadiyah Makassar yang mengatakan :

"Dosen yang melakukan aktifitas/ proses pembelajaran di Fakultas Agama Islam tetapi tidak mengikuti aturan yang ada di Fakultas Agama Islam akan diberikan sebuah sangsi dengan mengurangi jam mengajar dalam mata kuliah, bahkan sangsi tegasnya ialah tidak diberi lagi mata kuliah untuk mengajar dijurusan pendidikan agama islam Universitas Muhammadiyah Makassar" (Wawancara, 11 Desember 2014).

Hal ini dilakukan sebagai upaya memberikan efek jera kepada dosen pendidikan agama islam yang tidak mengikuti aturan-aturan yang ada dijurusan pendidikan agama islam sehingga dalam mencapai efektifitas dalam pembelajaran dapat terwujudkan dengan baik sesuai dengan harapan secara bersama.

\section{KESIMPULAN}

Adapun kesimpulan dari hasil penelitian yaitu:

1. Peningkatan Kinerja dosen di Fakultas Agama Islam sangat memberi kontribusi kepada Fakultas sebagai proses peningkatan mutu Pendidikan Agama Islam. Dalam mewujudkan kinerja dosen yang baik, semua pihak perlu terlibat terutama pihak pimpinan fakultas yang menjadi elemen penting dalam mengukur kinerja dosen di jurusan Pendidikan Agama Islam.

2. Kinerja dosen dapat diukur dengan melihat hal yang dilakukan selalu terbaik untuk mahasiswa. Dalam hasil tabulasi penelitian dapat dikatakan Dosen pendidikan agama islam cukup baik dalam mengefektifitaskan pembelajaran di jurusan pendidikan agama islam. Dosen di prodi pendidikan agama islam sudah mengikuti ketentuan yang ada di fakultas agama islam seperti mengikuti kurikulum dalam proses belajar mengajar, menggunakan media dan metode efektif dalam pembelajaran, pemberian motivasi dan yang terpenting santun dalam berbusana .

3. Selain itu, untuk mewujudkan kinerja dosen yang baik dengan meningkatkan kreatifitas diproses belejar mengajar melalui media IT. Pimpinan Fakultaspun perlu campur tangan dengan mengevaluasi kerjakerja dosen pendidikan agama islam setiap semester dengan mengontrol absensi mata kuliah yang diajarkannya. Hal yang terpenting lainnya ialah memberikan sangsi kepada dosen yang melakukan pelanggaran (tidak sesuai aturan fakultas) didalam proses belajar mengajar dengan mengurangi mata kuliah yang diajarkan atau di non aktifkan dari status dosen pendidikan agama islam. 


\section{DAFTAR PUSTAKA}

A.M. Sardiman. 2012. Interaksi \& Motivasi Belajar Mengajar. Jakarta: PT. RajaGrafindo Persada

Abdussalam, Suroso. 2011. Sistem Pendidikan Islam. Bekasi Barat: PT elba Fitrah Mandiri Sejahtera Arikunto, Suharsimi. 2005. Manajemen Penelitian. Jakarta: Rineka Cipta

Azwar, Saifuddin. 1997. Metode Penelitian. Yogyakarta: Pustaka Pelajar

Baharuddin dan Mulyono. 2005. Manajemen Strategik Peningkatan Kinerja Dosen Perguruan Tinggi Agama Islam. UIN Malang. Skripsi

Bambang Swasto Sunuharjo, 1995.

Pengembangan Sumber Daya Manusia Serta Pengaruhnya Terhadap Kinerja dan Imbalan (Suatu Kajian terhadap Dosen Perguruan Tinggi Swasta Pada Kopertis Wilayah VII Jawa Timur) Disertasi, Program Pascasarjana, Universitas Airlangga, Surabaya.

Daradjat, Zakiah, dkk. 1992. Ilmu Pendidikan Islam. Jakarta: Bumi Aksara. Cet ke-2

Hamalik, Oemar. 2010. Psikolgi Belajar dan Mengajar. Bandung: Sinar
Baru Algensindo

Hamalik, Oemar (dalam Sitiatava Rizema Putra ) 2012. Desain

Belajar Mengajar Kreatif Berbasis Sainis. Yogyakarta: Diva Press

Ilyasssin, Muhammad. 2010. Budaya Organisasi Bagi Peningkatan Kinerja Dosen. Samarinda: STAIN.p.6

Jani, 2009. Pengaruh Motivasi Kerja dan Kompetensi terhadap Aktivitas dalam Pelaksanaan

Keputusan Menteri Negara Koordinator Bidang Pengawasan Pembangunan dan Pendayagunaan Aparatur Negara Nomor : 38/KEP/MK.WASPAN/8/1999 Tentang Jabatan fungsional Dosen dan Angka Kredit.

Mahyudin, Rahil (dalam Sitiatava

Rizema Putra ) 2012. Desain

Belajar Mengajar Kreatif

Berbasis Sainis. Yogyakarta:

Diva Press

Moleong, Lexy, J., 1990. Metodologi Penelitian Kualitatif. Bandung: PT. Remaja Rosdakarya. 